\title{
Effect of ventilation on indoor environmental quality in buildings
}

\author{
Peter Kapalo ${ }^{a}$, Anna Sedlákováb, Danica Košičanovác, Orest Voznyak ${ }^{\text {d }}$, \\ Ján Lojkovics ${ }^{\mathrm{e}}$, Pavol Siroczki ${ }^{\mathrm{f}}$ \\ ${ }^{a, b, c, e}$ Technical University of Kosice, Faculty of Civil Engineering, Vysokoskolska 4, 04200 Kosice, Slovakia \\ ${ }^{d}$ National University - Lviv Polytechnic, Lviv, Ukraine \\ ${ }^{f}$ Pavol Jozef Safarik University in Kosice, Jesenná 5, 04001 Kosice, Slovakia
}

\begin{abstract}
Living standard of people is increasing significantly recently and due to this fact energy requirements are also increasing. At the Technical University in Kosice a research examining the quality of indoor environment is carried out. There exists a constructed research centre, where an experimental house with passive standards in terms of building structures is designed. Heating and ventilation can be modelled in the house. Equipment is designed on the basis of calculated balances for the needs of heat, hot water demand and the need for ventilation of the building.

This paper highlights the importance of environmental protection regarding the reduction of energy consumption while keeping the living standard. In low energy houses, up to $80 \%$ of the total heat is consumed for the heating of fresh air for a comfortable environment. The aim of this article is to examine the effect of temperature, humidity, air velocity and $\mathrm{CO}_{2}$ concentration in regard to the human behaviour in indoor environment with natural ventilation, i.e. without a ventilation device, where ventilation is forced or an air conditioning.
\end{abstract}

Keywords: ventilation; airflow rate; legislative; carbon dioxide $\left(\mathrm{CO}_{2}\right)$, concentration.

\begin{tabular}{|l|}
\hline Nomenclature \\
Abbreviations \\
$\mathrm{CO}_{2} \quad$ carbon dioxide \\
$\mathrm{IDA} \quad$ category of indoor air \\
$\mathrm{C}-\mathrm{AQ}-0001 \mathrm{R}$ sensor unit for $\mathrm{CO}_{2}$ \\
$\mathrm{~S}-3541 \quad$ thermo-hydrometer \\
\hline
\end{tabular}

\section{Introduction}

Buildings with a low-level of energy consumption are trendy in Slovakia. In certain areas approx. 40\% of total energy consumption is spent just for heating buildings. The following statistical data are known according to the EuroACE [1]: $57 \%$ of global energy consumption in a building is spent for heating, $25 \%$ for heating domestic hot water, $11 \%$ for lighting and electric appliances and $7 \%$ for cooking.

According to studies [2] actual houses usually have larger floor areas, whereas the number of persons living in the house is reduced. This means a larger floor area per person and due this fact also consumption of the fresh air per square meter in the given house is reduced. Such a fact is very important with regard to the evaluation of rooms according to temperature, concentration of carbon dioxide and relative air humidity [3].

The faculty of Civil Engineering in Kosice is performing research on indoor air quality. The experimental house is designed in passive standards in terms of building structures. The experimental house (Fig. 1) is located in a space, where outdoor temperature and relative humidity can be simulated. 


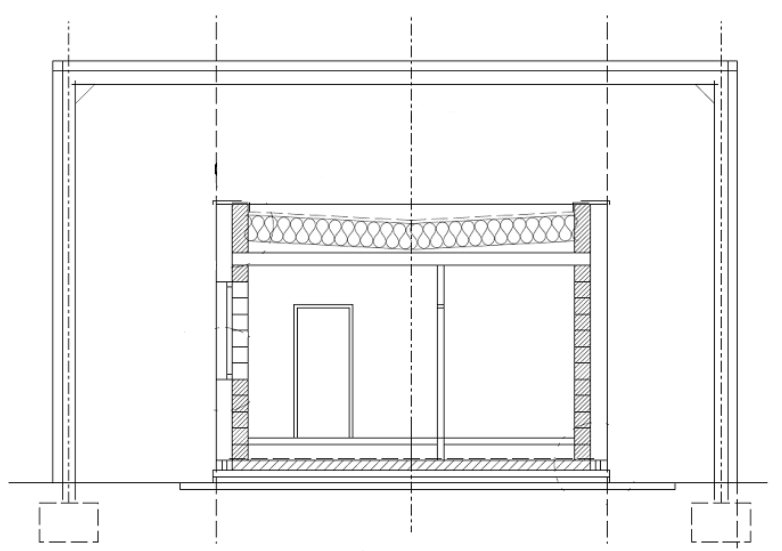

Fig. 1. Cross section of the experimental building

\section{Research Methods}

\subsection{Production of carbon dioxide}

The people that are in the room inhale air. Carbon dioxide and other gases are in the exhaled air. In the outdoor air about $400 \mathrm{ppm}$ of carbon dioxide can be typically measured. When the carbon dioxide concentration reaches 1000 to 1500 ppm, undesirable feelings occur in persons [4], [5]. Higher concentrations are very undesirable - see Table 1.

Table 1. The effect of increased $\mathrm{CO}_{2}$ concentrations on the human body [6]

\begin{tabular}{ll}
\hline Concentrations of CO2 $(\mathrm{ppm})$ & The effect on the body \\
\hline $330-400$ & Outdoor air - fresh air \\
$450-1000$ & The pleasant feeling - good level \\
$1000-2000$ & Sleepiness - bad air \\
$2000-5000$ & Possible headaches, \\
over 5000 & Discomfort, rapid heart rate \\
over 15000 & Problems with breathing \\
over 30000 & Dizziness and indisposition \\
over 60000 & Blackout \\
\hline
\end{tabular}

Exhaled air contains $3.6-4.2 \%$ of $\mathrm{CO}_{2}$ [7]. Experimental measurements were carried out in a classroom where several people carried out work in a seated position. We calculated mass flows of $\mathrm{CO}_{2}$ expecting an average inhale / exhale with a capacity of 0.5 litre and the intensity of respiration between 10 and 18 breaths per minute. Calculated values of the mass flow for various intensities of respiration (10 to 18 per minute) with the volume of one inhale / exhale 0.5 litres are presented in Table 2 .

Table 2. Calculated values of mass flow of $\mathrm{CO}_{2}$ with expected inhale / exhale volume of 0.5 litre

\begin{tabular}{|c|c|c|c|c|c|c|c|c|c|}
\hline Intensity of respiration $(1 / \mathrm{min})$ & 10 & 11 & 12 & 13 & 14 & 15 & 16 & 17 & 18 \\
\hline Mass flow of $\mathrm{CO}_{2}(\mathrm{mg} / \mathrm{s})$ & 6.55 & 7.20 & 7.86 & 8.51 & 9.17 & 9.82 & 10.47 & 11.13 & 11.78 \\
\hline
\end{tabular}

From the data of $\mathrm{CO}_{2}$ concentration obtained by measurements carried out when people stayed in the classroom and from the calculated ventilation rate by infiltration we determined the value of mass flow of $\mathrm{CO}_{2}$. The discovered actual production of $\mathrm{CO}_{2}$ was $8.1 \mathrm{mg} / \mathrm{s}$ per person.

\subsection{Indoor air quality}

For indoor air quality in Slovakia European standards STN EN 13779 [8] and STN EN 15215 [9] are valid, which characterize the four degrees for air quality: IDA 1 till IDA 4. The degrees of quality of indoor air are further described in Table 3. 
Table 3. Indoor air quality

\begin{tabular}{ll|ll}
\hline Cat. & Quality of indoor air & Cat. & Qualitative description of indoor air \\
\hline according to STN EN 13779 [8] & \multicolumn{3}{|l}{ according to STN EN 15251 [9] } \\
\hline IDA 1 & High & I. & High indoor air quality for hospitals and the like. \\
IDA 2 & Medium & II. & Standard level for new and reconstructed buildings. \\
IDA 3 & Moderate & III. & Acceptable level for existing buildings \\
IDA 4 & Low & IV. & Only limited acceptable level \\
\hline
\end{tabular}

In our experimental house we required air quality IDA 2, where a maximum $\mathrm{CO}_{2}$ concentration of $1000 \mathrm{ppm}$ is allowed.

\subsection{Experimental measurement of air parameters}

In order to determine the values of carbon dioxide concentration a $\mathrm{CO}_{2}$ sensor unit C-AQ-0001R (Fig. 2a) was used. To measure the air temperature and relative humidity we used a thermo-hydrometer measuring device S-3541 (Fig. 2b).

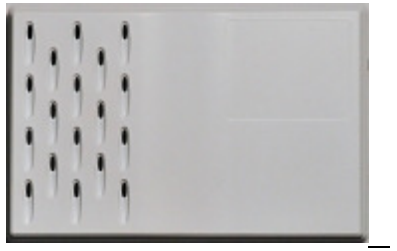

(a)

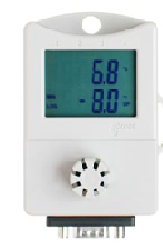

(b)

Fig. 2. Measuring device: (a) $\mathrm{CO}_{2}$ concentration sensor unit C-AQ-0001R (b) Thermo-hydrometer measuring device S-3541

Several experimental measurements were carried out. Measurements were carried out in winter on different days in the room - see Figure 3.

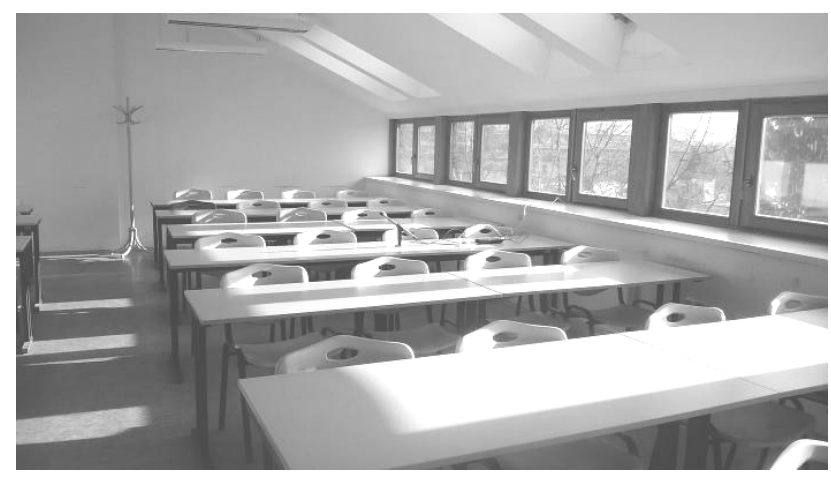

Fig. 3. Measured room

The assessed room is located on the fifth floor of a five storey building. During the period of measurement the number of people present in the room varied. The dimensions of the classroom are: length $10.92 \mathrm{~m}$, width $5.63 \mathrm{~m}$ and height $1.94-$ $4.10 \mathrm{~m}$. The internal volume of the room is $199 \mathrm{~m}^{3}$. The floor area of the room is $65 \mathrm{~m}^{2}$.

During the presence of persons in the room our measuring devices recorded indoor air temperature, indoor air humidity and concentration of carbon dioxide. Characteristic data of measurements in this room are documented in Table 4.

Table 4. Characteristic data of measurements

\begin{tabular}{|c|c|c|c|c|c|c|}
\hline $\begin{array}{l}\text { Number of } \\
\text { measurement }\end{array}$ & $\begin{array}{l}\text { Date of } \\
\text { measurement }\end{array}$ & $\begin{array}{l}\text { Number of women } \\
(-)\end{array}$ & $\begin{array}{l}\text { Number of men } \\
(-)\end{array}$ & $\begin{array}{l}\text { Mass of persons } \\
(\mathrm{kg} / \text { per })\end{array}$ & $\begin{array}{l}\text { People age } \\
\text { (years/per) }\end{array}$ & $\begin{array}{l}\text { Area per person } \\
\left(\mathrm{m}^{2} / \text { per }\right)\end{array}$ \\
\hline 1 & $01 / 07 / 2014$ & 5 & 12 & 69 & 23 & 3.5 \\
\hline 2 & $01 / 09 / 2014$ & 2 & 2 & 75 & 24 & 15.0 \\
\hline 3 & $01 / 14 / 2014$ & 2 & 7 & 75 & 23 & 6.7 \\
\hline 4 & $01 / 16 / 2014$ & 6 & 11 & 67 & 23 & 3.5 \\
\hline 5 & $01 / 20 / 2014$ & 4 & 12 & 70 & 23 & 3.8 \\
\hline 7 & $01 / 24 / 2014$ & 1 & 7 & 83 & 28 & 7.5 \\
\hline 8 & $01 / 24 / 2014$ & 1 & 7 & 83 & 28 & 7.5 \\
\hline
\end{tabular}


The number of persons present in the room during each measurement is variable. Every person, who was is in the room, expressed their feelings by filling out a questionnaire - see Figure 4.

\begin{tabular}{|c|c|c|}
\hline \multicolumn{2}{|c|}{$\begin{array}{lc}\text { Age: } & \text { years } \\
\text { Weight: } & \mathrm{kg}\end{array}$} & \multirow{3}{*}{$\begin{array}{l}\text { Date of evaluation: } \\
\text { Total time spent in the indoor environment: _._. hours ___. minutes } \\
\text { Number of minutes spent in the indoor environment from the start of } \\
\text { filling up the questionnaire: } \quad \text { minutes }\end{array}$} \\
\hline \multicolumn{2}{|c|}{ Sex: } & \\
\hline$\square$ male & $\square$ female & \\
\hline
\end{tabular}

\begin{tabular}{|c|c|c|}
\hline $\begin{array}{l}\text { How do you rate your thermal } \\
\text { sensation? }\end{array}$ & $\begin{array}{l}\text { How do you perceive the } \\
\text { temperature? }\end{array}$ & $\begin{array}{l}\text { Do you want the room } \\
\text { temperature? }\end{array}$ \\
\hline $\begin{array}{l}\square \text { Hot } \\
\square \text { Warm } \\
\square \text { Slightly warm } \\
\square \text { Neutral } \\
\square \text { Slightly cool } \\
\square \text { Cool } \\
\square \text { Cold }\end{array}$ & 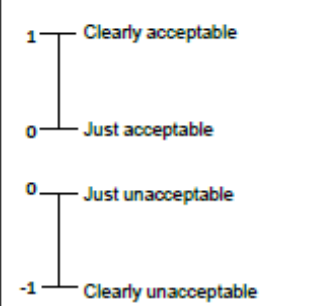 & $\begin{array}{l}\square \text { Higher } \\
\square \text { No change } \\
\square \text { Lower }\end{array}$ \\
\hline $\begin{array}{l}\text { How do you perceive the bad } \\
\text { smell intensity? }\end{array}$ & $\begin{array}{l}\text { How do you perceive the scent } \\
\text { intensity? }\end{array}$ & $\begin{array}{l}\text { How do you perceive the air } \\
\text { quality }\end{array}$ \\
\hline $\begin{array}{l}\square \text { None } \\
\square \text { Weak } \\
\square \text { Moderate } \\
\square \text { Strong } \\
\square \text { Very strong } \\
\square \text { Overpowering }\end{array}$ & $\begin{array}{l}\square \text { None } \\
\square \text { Weak } \\
\square \text { Moderate } \\
\square \text { Strong } \\
\square \text { Very strong } \\
\square \text { Overpowering }\end{array}$ & $\begin{array}{l}{ }_{0}^{1}{ }_{0} \text { Clearly acceptable } \\
0 \\
0\end{array}$ \\
\hline
\end{tabular}

Fig. 4. Questionnaire for the subjective evaluation the indoor environment

The evaluation of measurements and subjective evaluation of the indoor environment are processed in the following chapter (see 3. Results and discussion).

\section{Results and discussion}

\subsection{Measurement of air parameters}

A total of eight measurements were carried in the classroom during examinations, when students elaborated answers to a given set of questions. After the written examination all students left the classroom, which remained empty and locked with closed windows. The $\mathrm{CO}_{2}$ concentration in the classroom decreased in this period due to air infiltration from leaky windows. In Figure 5 the course of $\mathrm{CO}_{2}$ concentration for the total length of stay of people in the classroom can be seen. Figure 5 shows the measured air parameters $\left(\mathrm{CO}_{2}\right.$ concentration, indoor air temperature and relative humidity) depending on time.

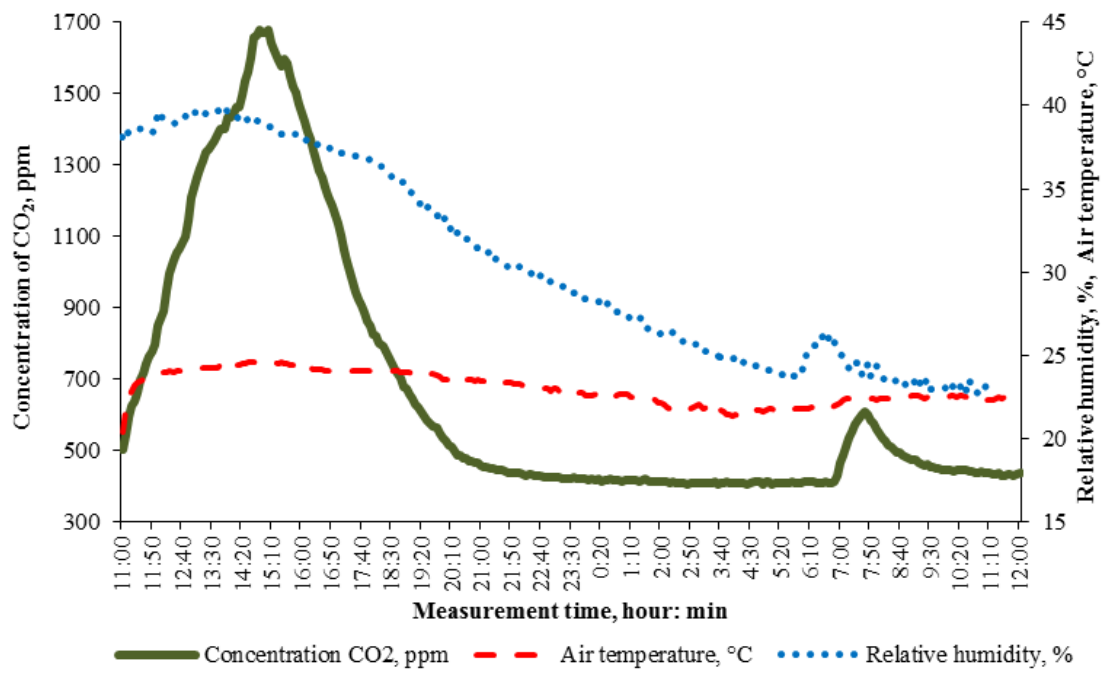

Fig. 5. Measured values of indoor air temperature, concentration of carbon dioxide and relative humidity 
Experimental results for all measurements are presented in the Table 5.

Table 5. Measured air parameters

\begin{tabular}{llllll}
\hline $\begin{array}{l}\text { Number of } \\
\text { measurement }\end{array}$ & $\begin{array}{l}\text { Number of people } \\
(-)\end{array}$ & $\begin{array}{l}\text { Length of stay } \\
(\mathrm{min})\end{array}$ & $\begin{array}{l}\text { Average temperature in the room } \\
\left({ }^{\circ} \mathrm{C}\right)\end{array}$ & $\begin{array}{l}\text { Average air humidity } \\
(\%)\end{array}$ & $\begin{array}{l}\text { Maximum concentration of } \mathrm{CO}_{2} \\
(\mathrm{ppm})\end{array}$ \\
\hline 1 & 17 & 65 & 21 & 40 & 1685 \\
2 & 4 & 70 & 21 & 51 & 809 \\
3 & 9 & 95 & 22.7 & 29 & 1546 \\
4 & 17 & 90 & 22.8 & 33.5 & 1707 \\
5 & 16 & 90 & 22.9 & 43.3 & 2141 \\
6 & 7 & 106 & 24.5 & 25 & 1017 \\
7 & 8 & 240 & 26.8 & 23 & 1566 \\
8 & 8 & 165 & 28.2 & 23 & 1347 \\
\hline
\end{tabular}

The data specified in Tables 4 and 5 indicate a direct correlation of $\mathrm{CO}_{2}$ concentration and the weight of people. It can be concluded, that people with higher weight produce more carbon dioxide than lighter people.

\subsection{Indoor air quality}

After finishing work persons completed a questionnaire, in which they indicated their perception on the room temperature and perception on the odor and smell. Results of subjective opinions on the quality of indoor environment are processed in Table 6.

Table 6. Perceived indoor air quality

\begin{tabular}{l|lll|lll}
\hline \multirow{2}{*}{$\begin{array}{l}\text { Number of } \\
\text { measurement }\end{array}$} & \multicolumn{3}{l|}{$\begin{array}{l}\text { Perceive the air temperature } \\
\text { Number of people (\%) }\end{array}$} & \multicolumn{2}{l}{$\begin{array}{l}\text { Perceive the scent intensity } \\
\text { Number of people (\%) }\end{array}$} \\
\cline { 2 - 7 } & $\begin{array}{l}\text { Clearly } \\
\text { acceptable }\end{array}$ & $\begin{array}{l}\text { Just } \\
\text { acceptable }\end{array}$ & $\begin{array}{l}\text { Just } \\
\text { unacceptable }\end{array}$ & none & Weak & moderate \\
\hline 1 & $\mathbf{5 9}$ & 41 & 0 & $\mathbf{5 3}$ & 35 & 12 \\
2 & 0 & $\mathbf{1 0 0}$ & 0 & 0 & $\mathbf{7 5}$ & 25 \\
3 & $\mathbf{6 7}$ & 33 & 0 & 0 & 44 & $\mathbf{5 6}$ \\
4 & $\mathbf{5 3}$ & 47 & 0 & 29 & $\mathbf{5 3}$ & 18 \\
5 & $\mathbf{8 1}$ & 19 & 0 & $\mathbf{5 0}$ & 37 & 13 \\
6 & $\mathbf{7 1}$ & 29 & 0 & $\mathbf{8 6}$ & 0 & 14 \\
7 & 13 & $\mathbf{6 3}$ & 24 & $\mathbf{6 3}$ & 25 & 12 \\
8 & 13 & 38 & $\mathbf{4 9}$ & 13 & $\mathbf{6 3}$ & 24 \\
\hline
\end{tabular}

Impact of temperature on the people (in the room) according to the questionnaires elaborated in Figure 6. Individual measurements are evaluated by the effect of temperature (number from 1 to 8 ) and sorted by temperature in the charts - see Figure 6 . The order of measurements is: 1,2, 3, 4, 5, 6, 7 and 8 . People reacted to the indoor air temperature accurately.
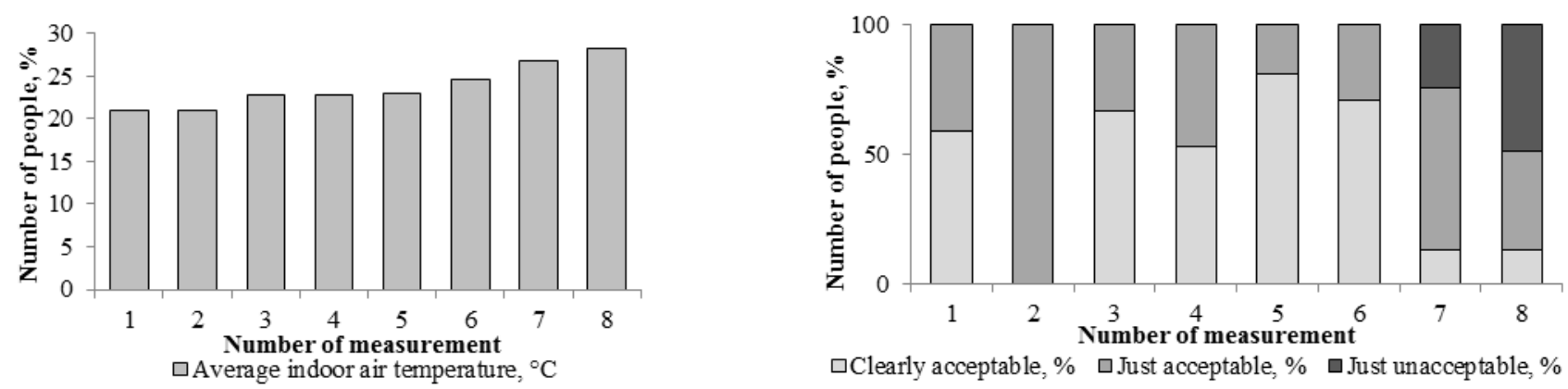

Fig. 6. Impact of temperature on the people 
From Figure 6 it can be seen that people reacted to the indoor air temperature accurately. When the temperature in a room is increased, so the number of dissatisfied persons increases.

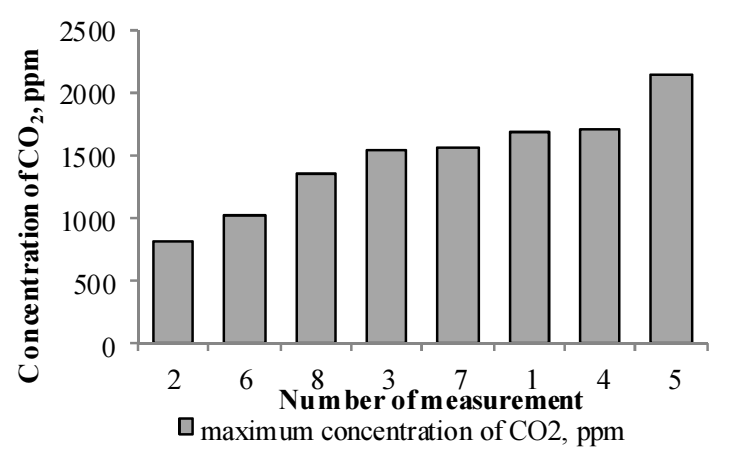

Fig. 7. Impact of concentration of carbon dioxide on the people

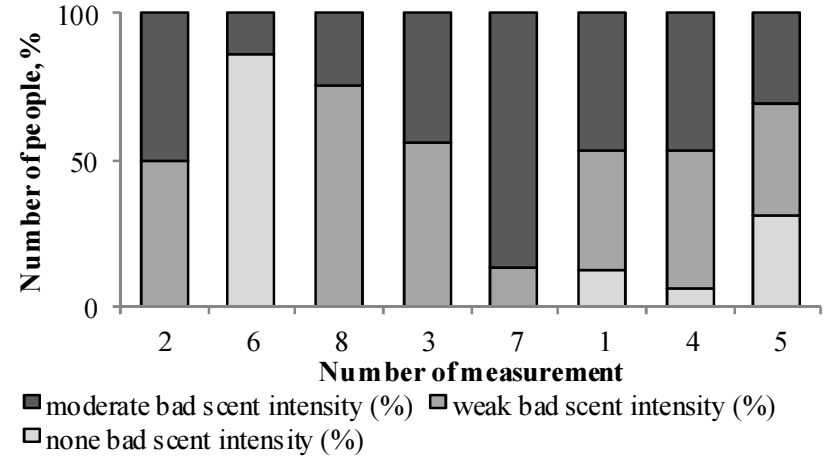

$\square_{\text {none bad scent intensity (\%) }}$

Impact of concentration of carbon dioxide can be evaluated directly proportional with odor. The impact of concentration of carbon dioxide according to the questionnaires is elaborated in Figure 7. Individual measurements are evaluated by the effect of odor intensity (number from 1 to 8 ) and sorted by the concentration of carbon dioxide in the charts. The order of measurements is: $2,6,8,3,7,1,4$ and 5 .

From Figure 7 is can be concluded, that people reacted to bad scent intensity less accurately. When the $\mathrm{CO}_{2}$ concentration in room is increased, people are little responsive to bad scent.

\section{Conclusions}

On the basis of our research it can be stated that heavier people produce more $\mathrm{CO}_{2}$ than people with less weight. During future continuations of this line of research it will be interesting to investigate the correlation between a weight of person and $\mathrm{CO}_{2}$ production more closely.

From the questionnaires we can conclude that people react to temperature changes in a room more accurately than to changes in odor caused by the changes of $\mathrm{CO}_{2}$ concentration. Increasing $\mathrm{CO}_{2}$ concentration is hardly perceived by persons, especially when they constantly inside the room and focused on a particular task. His performance deteriorates uncontrollably and tiredness occurs sooner than usual. This is caused by the persons' acclimation to the deteriorating environment. Persons only react to the changing air quality after a critical level is surpassed, which is individual for every person.

With increasing $\mathrm{CO}_{2}$ concentration slower reactions to proposed tasks can be expected. The effect of insufficient ventilation on a person's performance will be investigated in more detail in our future research.

\section{Acknowledgements}

This article was elaborated in the framework of the project VEGA 1/0405/13 and KEGA 052TUKE-4/2013.

\section{References}

[1] EuroACE. 2004. Towards Energy Efficient Buildings in Europe. Final report June, 2004.

[2] Vaňo, B.; Jurčová, D.; Mészáros, J. 2002. Prognosis of development population in Slovakia by the year 2050. Institute of informatics and statistics. Bratislava, 11.2002, Acts.

[3] Kapalo, P.; Pauliková, A. 2012. Effect of Ventilation on Indoor Environment Quality in Low-Energy Buildings. Wooden buildings and ecological housing. Zvolen, Slovakia. 26.04.2012, p. 1-7. ISBN 978-80228-2356-2.

[4] Gebauer, G.; Rubínová, O.; Horká, H. 2005. Ventilation Technic.. ERA group, spol. s.r.o., Brno. ISBN 80-7366-027-X.

[5] Persily, A. 1997. Evaluating building IAQ and ventilation with indoor carbon dioxide. Transactions American society of heating refrigerating and air conditioning engineers, 1997, p. 193-204, ASHRAE.

[6] Doležílková, H. 2007. Residential microenvironment. PhD thesis. Czech Technical University in Prague, Faculty of Civil Engineering. 2007.

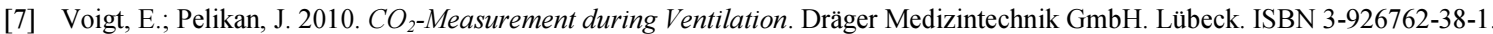

[8] STN EN 13779. 2005. Ventilation in non-residential buildings. General requirements for ventilation and air conditioning equipment. 2005.

[9] STN EN 15251. 2007. The input data of the internal environment of buildings in the design and assessment of energy performance of buildings - air quality, thermal environment, lighting and acoustic. 2007. 